УдК 349.4 (477)

DOI https://doi.org/10.32837/apdp.v0i90.3213

T. В. Лісова

\title{
ДЕЯКІ АКТУАЛЬНІ ПИТАННЯ ПРАВОВОГО ЗАБЕЗПЕЧЕННЯ ВІДНОВЛЕННЯ ЗЕМЕЛЬ
}

Постановка проблеми. В умовах стрімкого погіршення стану земельних ресурсів в Україні невідкладного вирішення потребує одна з найскладніших проблем сьогодення - зупинення подальшого масштабного погіршення стану земель та їх відновлення. Основу формування державної політики у сфері охорони й відновлення земель в Україні становить Угода про асоціацію між Україною та ЄС. Держава прийняла низку програмних документів, за якими взяла на себе певні зобов'язання, зокрема, про приєднання: а) до Рамкової конвенції ООН про зміну клімату (Convention on Climate Change, 1992), б) до Конвенції ООН про боротьбу з опустелюванням (United Nations Convention to Combat Desertification, UNCCD, 1994), в) до Конвенції ООН про охорону біологічного різноманіття (Convention on Biological Diversity, 2000). Сьогодні підвалини планування заходів відновлення земель у державі складають: Основні засади (стратегія) державної екологічної політики України на період до 2030 року, затверджені Законом України від 28 лютого 2019 р., № 2697-VIII, Концепція боротьби з деградацією земель та опустелюванням, затверджена розпорядженням Кабінету Міністрів України від 22 жовтня 2014 р., № 1024-р., Національний план дій щодо боротьби з деградацією земель та опустелюванням, затверджений розпорядженням Кабінету Міністрів України 30 березня 2016 p., № 271-p.

Значна частина земель незалежно від їх цільового призначення вимагає проведення невідкладних заходів відновлення. Правові норми, спрямовані на відновлення стану земель, закріплені в нормативно-правових актах різної юридичної сили, на жаль, мають переважно загальний або ж декларативний характер, позбавлені будь-якої систематизації, що призводить до виникнення юридичних прогалин і колізій у механізмі правової регламентації суспільних відносин, що стосуються відновлення земель. До того ж у чинному земельному законодавстві приписи щодо забезпечення відновлення земель чітко не розмежовані з приписами щодо їх охорони. Суспільні відносини у справі відновлення земель залишаються недостатньо врегульованими правовими положеннями законодавства, що позначається негативно й на судовій практиці. Наявність указаних недоліків правового забезпечення відновлення земель украй негативно впливає як на розвиток відповідних правовідносин, так і на стан земель у цілому.

Аналіз останніх досліджень і публікацій. Більшість наукових праць присвячено дослідженню питань правової охорони земель. Проблеми ж відновлення земель розглядалися вітчизняними правознавцями лише фрагментарно.

Зокрема теоретичні питання щодо окремих заходів відновлення земель були досліджені на рівні дисертаційних досліджень. Йдеться про праці М.А. Дейнеги й А.Л. Місінкевич. 
Особливої уваги заслуговує монографічне дослідження П.Ф. Кулинича, в якій ученим запропоновано шляхи вдосконалення правового регулювання сільськогосподарського землекористування в Україні в контексті пріоритету вимог щодо відновлення й збереження земель сільськогосподарського призначення. Вагомий внесок у вивчення теоретико-методологічних і прикладних засад правової регламентації використання, відновлення й охорони грунтів здійснено Н.С. Гавриш.

Метою статті є дослідження сучасних проблем у сфері правового забезпечення відновлення земель.

Виклад основного матеріалу. Насамперед необхідно зазначити, що аналіз енциклопедичних і лінгвістичних літературних джерел дозволяє зробити висновок, що термін «відновлення» застосовується в контексті якісних властивостей земель (зокрема, родючості грунтів), стану порушених земель. Так, відповідно до Великого тлумачного словника сучасної української мови термін «відновлювати» означає повертати попередній вигляд чому-небудь пошкодженому, зіпсованому, зруйнованому [1, с. 182].

При цьому відбувається приведення стану земель від існуючого негативного до притаманного їм первісного якісного стану. Йдеться про певні позитивні зміни, в тому числі й грунтової родючості, а також про відновлення виконуваних землями функцій відповідно до їх цільового призначення. Відтворити землі як природний об'єкт неможливо.

Якісний стан земель характеризується сукупністю як позитивних, так і негативних їх властивостей. Доцільно зауважити, що терміни «відновлення» й «відтворення" не є тотожними. Водночас наведені терміни в чинному земельному законодавстві й у більшості наукових робіт учених, як правило, ототожнюються, причому як у працях представників юридичної доктрини, так і в працях науковців-грунтознавців.

Такий природний об'єкт, як землі, є взагалі невідтворюваним, їх неможливо створити як природний об'єкт, проте він є відновлюваним. Однак відновленню земель, на відміну від інших природних ресурсів, притаманна певна специфіка, яка полягає в тому, що відновленню підлягає стан земель (ідеться про відновлення ïx якісного стану, їх грунтів, належного стану порушених земель), а також функції, що виконують землі за їх основним цільовим призначенням. У широкому розумінні відновлення становить собою усунення погіршення стану земель.

Отже, доцільно розглядати відновлення земель як законодавчо забезпечену систему заходів, спрямованих на повернення землям їх первісного якісного стану, погіршеного через дію антропогенних або природних (стихійних) чинників, втраченої здатності виконувати ними певні функції, що випливають з їх основного цільового призначення, належного стану порушених земель шляхом здійснення їх рекультивації, консервації земель деградованих і малопродуктивних, меліорації земель та інших заходів, передбачених законодавством.

Відтворення природних об'єктів знаходить свій прояв через кількісні показники, ним охоплюється створення природних об'єктів. Йдеться про відтворення об’ єктів рослинного світу, в тому числі лісів, а також об'єктів тваринного світу. 
Очевидно, що рекультивація порушених земель, консервація деградованих і малопродуктивних земель, меліорація земель є правовими заходами їх відновлення. Як слушно наголошується у наукових працях, зазначені заходи стосуються безпосередньо якісного стану земель. Для земель сільськогосподарського й лісогосподарського призначення, які виконують функцію засобу виробництва, першоосновою слід вважати відновлення їх якісного стану, зокрема, родючості грунтів [2, с. 210].

Відновлення земель спрямовано як на відновлення їх якісного стану, так і на відновлення попереднього стану порушених земель. Адже при цьому відбувається руйнація верхнього шару землі.

Варто зазначити, що відновленню підлягають земельні ділянки, стан яких зафіксований у матеріалах Державного земельного кадастру. Якісний стан земель фіксується й у матеріалах проведення їх інвентаризації при здійсненні землеустрою, зокрема, шляхом проведення інвентаризації встановлюються якісні характеристики земельних ділянок, виявляються забруднені й такі, що потребують консервації деградовані земельні ділянки. Крім того, якісний стан зазначається й у матеріалах проведення нормативної грошової оцінки земель. Отже, якісний стан земельної ділянки, зафіксований у відповідній документації, і слід вважати первісним (з моменту передачі її у власність або надання у користування). Первісний, так би мовити, нульовий стан для кожного власника й землекористувача може бути різним, але треба орієнтуватися на матеріали Державного земельного кадастру. Будь-які зміни стану земельної ділянки повинні бути своєчасно відображені у документації Державного земельного кадастру. Уявляється доцільним, щоб нотаріуси при посвідченні договорів вимагали довідку про стан земель, щоб новий власник земельної ділянки був обізнаним стосовно наявного на момент відчуження земельної ділянки її стану.

Насамперед відновлення стосується земель, порушених унаслідок неправомірних дій, що викликали погіршення грунтового покриву, непридатний для використання стан земель унаслідок негативного впливу на них, як-то: забруднення земель радіоактивними й хімічними речовинами, відходами, стічними водами таін. Неправомірними діями можна вважати й зняття грунтового покриву без отримання на це спеціального дозволу на зняття грунтового покриву або за умов його анулювання. Проте в деяких випадках здійснюються також і правомірні дії, що викликають необхідність відновлення земель як сільськогосподарського, так і несільськогосподарського призначення. Так, правомірними є дії, що призвели до зміни структури рельєфу в результаті проведення гірничодобувних, геологорозвідувальних, будівельних та інших робіт за умови отримання спеціального дозволу на зняття грунтового покриву й наявності відповідного робочого проєкту рекультивації земель.

Необхідність відновлення земель викликана різними чинниками. Перш за все негативно впливає на стан земель антропогенна діяльність: (а) неправильний напрямок обробітку грунту, (б) порушення організації території, (в) погіршення стану полезахисних лісосмуг, (г) недостатнє застосування протиерозійних заходів, (д) вирубування лісів, (е) руйнування схилів, (є) неналежний обробіток схилових земель, (ж) нехтування меліоративними заходами тощо. У той же час ерозію грун- 
тів можуть спричинити і природні катаклізми. Серед природних чинників найчастіше виокремлюють: (а) рельєф місцевості, (б) форму поверхні, (в) крутість та експозицію схилів, (г) протиерозійну стійкість грунтів, (д) зливовий характер опадів, (е) обсяги природних водозаборів, (є) товщину снігу, (ж) швидкість його весняного танення та ін.

Існують попередні й основні правові заходи відновлення земель. Так, про наявність попередніх заходів відновлення земель свідчать передбачені Земельним кодексом України обов'язки власників і користувачів земельних ділянок зберігати корисні властивості землі, за свій рахунок привести земельну ділянку в попередній стан у разі незаконної зміни її рельєфу, за винятком незаконної зміни рельєфу не власником такої земельної ділянки (статті 91, 96). 3 метою запобігання посиленню деградаційних процесів земель (зокрема, грунтів) вносяться мінеральні добрива, здійснюється промивання грунтів у випадках їх засолення, застосовуються відповідні режими зрошення та ін. Адже, як слушно підкреслюють фахівці-грунтознавці, правовий режим земель (зокрема, грунтів), спрямований на суворе дотримання власниками і землекористувачами науково обгрунтованих технологічних регламентів, високої культури поведінки щодо своєчасного запобігання та/або усунення явищ деградації грунтів і можливих еколого-економічних ризиків, пов'язаних з неправомірним, екологічно небезпечним землекористуванням [3, с. 92].

До попередніх заходів відновлення родючості грунтів належить також і запровадження сівозмін, у процесі чого враховуються затверджені нормативи оптимального співвідношення культур у різних природно-сільськогосподарських регіонах.

Отже, основними заходами відновлення є: консервація деградованих та малопродуктивних земель, рекультивація порушених земель, меліорація земель. Саме здійснення вказаних заходів відновлення земель одержало належне правове забезпечення. Проте, існують й інші заходи відновлення земель. Хоча, на жаль, їх впровадження сьогодні не врегульовано законодавством. До таких заходів насамперед належить фіторемедіація метод біологічного знешкодження забруднюючих речовин грунтів, що забезпечує відновлення їх родючості. Спеціалісти рекомендують його розглядати як один з напрямків рекультивації. При використанні цього методу коренями рослин поглинаються органічні забруднювачі, трансформуючись у безпечні для навколишнього природного середовища продукти. Заходом відновлення земель є також і біоремедіація, що поділяється на два види: біостимуляцію й біоаугментацію. Відновлення техногенно забруднених земель може здійснюватися шляхом зрізання грунтового шару, збирання забруднюючих речовин, екстракції паром тощо. Таким заходом є й так звана детоксикація, що може бути застосована як самостійний захід або при рекультивації порушених земель. Слід підкреслити, що проведення зазначених заходів у майбутньому повинно одержати закріплення у законодавстві.

Відновлення земель включає різні правові аспекти. Так, залежно від його мети виокремлюється відновлення родючості грунтів земель сільськогосподарського призначення, продуктивності земель лісогосподарського призначення, відновлення з метою виконання ними інших функцій (якщо йдеться про землі інших категорій). 
Заходи відновлення здійснюються як на загальнодержавному, регіональному рівнях, так і на локальному рівні, що здійснюються власниками й користувачами, в тому числі орендарями земельних ділянок. За роллю антропогенного чинника слід виокремити природне і штучне відновлення земель. Так, проведення рекультивації порушених земель, їх меліорації забезпечує їх штучне відновлення. Консервація земель сприяє їх природному відновленню, внаслідок чого спостерігається утворення перелогів і відбувається самовідновлення земельної ділянки. За джерелом правового забезпечення відновлення земель провадиться за наявності підстав і в порядку, визначених законом (ідеться про їх меліорацію), і згідно з підзаконними нормативно-правовими актами (йдеться про консервацію земель).

Досить важливим є те, що при здійсненні заходів відновлення земель, особливо грунтів, необхідно брати до уваги поділ території України на грунтовоекологічні зони.

Крім того, є сенс вести мову і про відновлення стану земельної ділянки і прав на землю, зокрема, про повернення самовільно зайнятих земель (ідеться про відновлення у більш широкому сенсі). Так, поверненню самовільно зайнятих земельних ділянок повинно передувати їх приведення у попередній, придатний для використання стан шляхом знесення самовільно збудованих будівель і споруд, відновлення порушеного рельєфу земельних ділянок тощо.

Сьогодні, як слушно зазначається у наукових працях, повернення самовільно зайнятих земельних ділянок є прикладом заходу з усунення порушень земельного законодавства [4, с. 41]. Відновлення земель є елементом захисту прав на них. Слід підкреслити, що зазначений вище спосіб захисту порушених прав знаходить свій прояв через рекультивацію порушених земель, проведення консервації деградованих і малопродуктивних земель, а також здійснення меліоративних та інших заходів їх відновлення.

Отже, відновлення стану земельної ділянки, який існував до порушення прав, як правило, вважають речово-правовим способом захисту. Проте його можна розглядати і як зобов'язально-правовий спосіб захисту. Так, зустрічаються випадки втрати первісного якісного стану, порушення рельєфу земельних ділянок унаслідок дій орендаря. Отже, у цьому разі порушуються права суб'єктів, які перебувають у договірних відносинах (зокрема, власника земельної ділянки). Згідно з постановою Кабінету Міністрів України «Про затвердження Типового договору оренди землі» після припинення дії договору орендар має повернути орендодавцеві земельну ділянку (земельні ділянки) у стані, не гіршому порівняно з тим, у якому він одержав її в оренду. Отже, при включенні відповідного обов'язку орендаря до тексту договору оренди як однієї з умов останнього, йдеться про зобов'язально-правовий спосіб захисту прав власника земельної ділянки.

Надзвичайно актуальним постає питання стосовно правової природи відновлення земель, для з'ясування якої насамперед доцільно звернути увагу на співвідношення відновлення й охорони земель, адже в наукових працях відновлення тлумачиться як напрям охорони земель.

Охорона й відновлення земель є обов'язком власників земельних ділянок і землекористувачів. Заходи охорони земель спрямовані на забезпечення раціонального 
використання земель, запобігання їх засміченню й забрудненню, гарантування особливого режиму використання земель природоохоронного, оздоровчого, рекреаційного й історико-культурного призначення. Заходи охорони земель здійснюються як на державному рівні (йдеться про зазначені вище функції управління), так і на локальному (при використанні земельних ділянок їх власниками та користувачами). Йдеться про їх раціональне використання, виконання обов'язків щодо додержання вимог законодавства про охорону довкілля, а також про збереження корисних властивостей землі.

Отже, відновленню земель притаманна певна специфіка. Його заходи здійснюються, коли відбулося погіршення якісного стану земель сільськогосподарського призначення, зокрема, родючості грунтів, порушення попереднього стану земель у разі зміни їх рельєфу, а також у разі неможливості виконання землями відповідних функцій згідно з їх цільовим призначенням.

У зв'язку з вищевикладеним надзвичайно важливим залишається питання щодо правової природи відновлення земель, установлення місця правових норм, які регулюють суспільні відносини з відновлення земель у системі права.

Правові норми, як відомо, утворюють відповідну галузь права через окремі правові інститути. Ці норми діють у складі галузі права, проте відрізняються від інших галузевих норм певною своєрідністю. У теорії права загальновизнаною $€$ точка зору, що правовим інститутом є виокремлена група норм права, яка регулює той чи інший вид однорідних суспільних відносин.

Правовими нормами, спрямованими на забезпечення відновлення земель, оперують у разі погіршення чи втрати якісного стану земель сільськогосподарського призначення, зокрема, родючості грунтів, порушення попереднього стану земель у випадку зміни їх рельєфу, а також при неможливості виконання землями тих чи інших функцій згідно з їх цільовим призначенням. Йдеться про зниження або втрату первісного якісного стану земель. Наприклад, під час бонітування грунтів спостерігається зниження оцінки якості грунтів через погіршення їх природних властивостей. Зміна властивостей грунтів обов'язково підлягає внесенню до земельно-кадастрової документації, зокрема, до Поземельної книги, до агрохімічного паспорта поля чи земельної ділянки. Така паспортизація здійснюється з метою контролю за зміною показників родючості, забруднення грунтів хімічними речовинами. Якщо вказані показники змінюються в бік погіршення якості грунтів, виникає необхідність відновлення їх родючості.

Заходи охорони й відновлення земель розділені між собою часовими рамками. Заходи охорони спрямовані переважно на забезпечення раціональної, цільової експлуатації земель, попередження погіршення їх стану, забруднення й засмічення, забезпечення особливого режиму використання земель природоохоронного, оздоровчого, рекреаційного й історико-культурного призначення. Про обов'язки власників і користувачів земельних ділянок щодо охорони земель ідеться у Земельному кодексі України, яким закріплено, що вказані суб'єкти зобов'язані додержуватися вимог законодавства про охорону довкілля, здійснювати підвищення родючості грунтів, зберігати інші корисні властивості землі, підтримувати протиерозійні споруди, мережі зрошувальних і осушувальних систем (статті 91, 96). Якщо ж реа- 
лізація цих заходів охорони не дала очікуваного результату (тобто заходи охорони не виявилися ефективними або взагалі не здійснювалися), а негативні наслідки щодо стану земель і зниження якісних показників Ірунтів (ґрунтової родючості) настали, необхідним є проведення заходів відновлення.

Після відновлення якісного стану земель (в тому числі їх грунтової родючості), стану порушених земель, а також функцій, що вони виконують за основним цільовим призначенням, землі знову стають об'єктом правовідносин з охорони.

Отже, підсумуємо, що правові норми, що регулюють суспільні відносини у сфері відновлення земель, можна вважати самостійним правовим інститутом, який характеризується особливим суб'єктним складом, йому притаманні специфічні поняття, законодавчі конструкції, як-то: порушені землі; деградовані земельні угіддя; деградовані землі; малопродуктивні землі; техногенно забруднені землі; деградація земель; деградація грунтів; земельні ділянки з еродованими, перезволоженими, з підвищеною кислотністю або засоленістю грунтами; несприятливий водний режим; перезволожені, переосушені землі; консервація земель; рекультивація порушених земель; землювання малопродуктивних угідь; меліорація земель; гіпсування грунтів; вапнування грунтів та ін.

Головним у правовідносинах відновлення земель є юридичний обов'язок, що знаходить свій прояв в активній поведінці зобов'язаної особи з метою забезпечення суб'єктивних прав інших суб'єктів. Насамперед варто підкреслити, що статті 90, 91, 95 і 96 Земельного кодексу України передбачають загальні права й обов'язки власників і користувачів земельних ділянок, і лише деякі з них належать до прав та обов'язків суб'єктів правовідносин щодо відновлення земель. Згідно зі ст. 91 Земельного кодексу України більшість обов’язків власників земельних ділянок спрямовані на забезпечення охорони останніх, на підвищення родючості грунтів і збереження інших корисних властивостей землі. Серед обов'язків власників земельних ділянок у сфері відновлення земель згідно зі ст. 91 розглядуваного кодексу можна також виокремити: приведення за свій рахунок земельної ділянки у попередній стан у разі незаконної зміни її рельєфу, за винятком здійснення такої зміни не власником земельної ділянки, коли ця процедура здійснюється за рахунок особи, яка незаконно змінила рельєф. Відновлювати земельні ділянки повинні як їх власники, так і користувачі у процесі їх експлуатації. У цьому випадку існує єдиний об’єкт використання, охорони й відновлення - земельна ділянка.

Проте в земельному законодавстві не зазначено обов'язку власників і користувачів земельних ділянок відновити втрачену родючість грунтів та інші корисні властивості землі у процесі господарської діяльності. Адже навіть за дбайливого здійснення регулярного підвищення рівня родючості грунтів і збереження інших корисних властивостей землі, ані власники земельних ділянок, ані землекористувачі не застраховані як ні від стихійних сил природи, ні від дій сторонніх осіб, унаслідок чого погіршується первісний якісний стан земель, виникають і набувають поширення процеси їх деградації, порушення рельєфу. У зв'язку із цим гостро постає проблема відновлення стану порушених земель, їх якісного стану і забезпечення виконання ними належних їм функцій. 
Вважаємо за необхідне закріпити обов'язок власників і користувачів у статтях 91 і 96 Земельного кодексу України відновлювати родючість грунтів й інші корисні властивості землі, а також приводити земельну ділянку в попередній стан у випадку зміни її рельєфу. На жаль, сьогодні спостерігається певна незацікавленість власників та користувачів земельних ділянок у здійсненні заходів з охорони й відновлення земель, що в певних випадках пов'язано з фінансовими проблемами. Підкреслимо, що власникам та користувачам земельних ділянок, які здійснюють їх раціональне використання, охорону, підвищують родючість грунтів, у разі погіршення якісного стану земель, втрати ними відповідних функцій своєчасно вживають заходи з їх відновлення, доцільно забезпечити надання певних пільг (податкових, кредитних). На противагу - на власників та землекористувачів за невжиття заходів щодо відновлення деградованих, забруднених і порушених земель мають бути накладені штрафи. Саме за рахунок таких коштів доцільно надавати відповідні пільги власникам землі і землекористувачам, які здійснюють належний обробіток землі, підвищують родючість грунтів, зберігають інші корисні властивості землі, ініціюють та здійснюють реалізацію заходів відновлення земель. Зазначене вище буде забезпечувати стимулювання як раціонального використання земель, їх охорони, так і проведення своєчасного відновлення земель. При цьому, зважаючи на розпорошеність повноважень у сфері забезпечення відновлення земель між Держгеокадастром та Держекоінспекцією, доцільно створити окремий орган (державне агентство або державну службу), що має сприяти більш ефективній діяльності у вказаній сфері.

Необхідність відновлення земель тісно пов'язана із застосуванням заходів юридичної відповідальності у розглядуваній сфері. В умовах слабкого економічного механізму є нагальна потреба посилити як адміністративну, так і кримінальну відповідальність. Зокрема, доцільно доповнити Кодекс України про адміністративні правопорушення спеціальною статтею про настання відповідальності за невиконання як власником земельної ділянки, так і землекористувачем обов'язку своєчасно розпочинати процедуру консервації деградованих, малопродуктивних і техногенно забруднених земель. Крім того, потрібно встановити кримінальну відповідальність за ігнорування відновлення якісного стану деградованих і малопродуктивних земель (передусім шляхом проведення їх консерваціі), рельєфу порушених земель шляхом здійснення їх рекультивації у встановлених законом випадках, якщо це потягло за собою тяжкі наслідки для довкілля і здоров’я людей.

Висновки. Відновленню земель необхідно надати системного характеру. Потрібно забезпечити дієву реалізацію положень законодавства щодо цієї процедури шляхом внесення змін до чинного законодавства, прийняття нових нормативно-правових актів у зазначеній сфері з метою належного здійснення відповідних заходів відновлення земель через обов'язки власників, користувачів земельних ділянок, інших суб'єктів, через дії яких відбулася втрата первісного якісного стану таких ділянок, порушення їх рельєфу, з одночасним посиленням їх відповідальності у сфері відновлення земель, а також створення й забезпечення функціонування належного рівня стимулювання власників земельних ділянок і землекористувачів до своєчасного відновлення земель паралельно з реальним надходженням коштів від держави до власників і користувачів земельних ділянок. 
В умовах істотного погіршення стану земель, стрімкого поширення деградаційних процесів у країні виникла нагальна потреба розроблення і прийняття Концепції відновлення деградованих, малопродуктивних і техногенно забруднених земель, а на її основі окремого Закону «Про відновлення земель», у якому необхідно закріпити дефініцію поняття «відновлення земель», його заходи, а також передбачити особливості відновлення земель різних категорій.

\section{Jimepamypa}

1. Великий тлумачний словник сучасної української мови / упоряд. В.Т. Бусел. Київ; Ірпінь: ВТФ «Перун», 2005. 1728 c.

2. Шульга М.В., Лейба Л.В. До питання про природноресурсове право. Природоресурсне право в системі права України: історія, свогодення, перспективи : матер. «круглого столу» (м. Харків, 30-31 жовтня 2015 р.). Харків: Оберіг, 2015. С. 208-211.

3. Балюк С.А., Гапєєв Л.В. Нормативно-правове забезпечення збереження грунтів і відтворення їхньої родючості з урахуванням зарубіжного досвіду. Раціональне використання грунтових ресурсів і відтворення родючості грунтів: організаційно-економічні, екологічні й нормативно-правові аспекти: моногр. / ред. : С.А. Балюк, А.В. Кучер. Харків: Смугаста тип., 2015. С. 84-107.

4. Сидоренко В.В. Правові проблеми повернення самовільно зайнятих земельних ділянок. Наук. вісн. Міжнар. гуманітар. ун-ту. Серія «Юриспруденція». 2014. № 10-2. Т. 2. С. 40-42.

\section{Анотація}

Лісова Т. В. Деякі актуальні питання правового забезпечення відновлення земель. - Стаття.

Статтю присвячено дослідженню проблем правового забезпечення відновлення земель. Наголошується, що значна частина земель незалежно від їх цільового призначення вимагає проведення невідкладних заходів відновлення. Звертається увага на декларативність правових приписів, спрямованих на відновлення стану земель, наявність юридичних прогалин і колізій у вказаній сфері. Запропоновано критерії розмежування понять «відновлення» та «відтворення», зауважено, що вказані поняття не $є$ тотожними. Наголошено на невідтворюваності земель як природного об'єкта.

Зазначено, що під час відновлення земель відбувається приведення стану земель від існуючого негативного до притаманного їм первісного якісного стану. Підкреслюється необхідність документальної фіксації змін стану земельної ділянки. Запропоновано дефініцію поняття «відновлення земель». Наголошено на різних його правових аспектах.

Запропоновано класифікацію заходів відновлення земель. Особливу увагу привернуто до основних заходів відновлення останніх. Пропонується відрізняти відновлення земель у широкому розумінні від вузького розуміння вказаного терміну. Наголошується на особливостях відновлення земель різних категорій. Акцентовано увагу, що насамперед землі потребують відновлення через неправомірні дії, водночас у певних випадках стан земель може бути погіршеним і через дії правомірні.

Досліджено правову природу норм, що регулюють суспільні відносини у сфері відновлення земель, ïx місце у системі земельного права. Запропоновано обгрунтовані критерії розмежування охорони та відновлення земель, проаналізовано їх взаємозв'язок.

Розглянуто особливості та місце відновлення стану земельної ділянки в системі способів захисту порушених прав на землю.

Проведено аналіз правових норм, які регламентують права та обов'язки у відповідній сфері. Виявлено прогалини у правовому регулюванні у вказаній царині та зроблені відповідні пропозиції. Зроблено висновок про слабкий економічний механізм та необхідність посилення юридичної відповідальності у сфері забезпечення відновлення земель. Зроблено висновок про необхідність надання відновленню системного характеру та розробки й прийняття необхідних нормативно-правових актів.

Ключові слова: відновлення, землі, грунти, якісний стан, родючість. 


\section{Summary}

Lisova T. V. Some topical issues of legal support of land restoration. - Article.

The article is devoted to the study of the problems of legal support of land restoration. It is emphasized that a significant part of the land, regardless of its purpose, requires urgent restoration measures. Attention is paid to the declarativeness of legal regulations aimed at restoring the state of lands, the presence of legal gaps and conflicts in this area. The criteria for distinguishing between the concepts of "restoration" and "reproduction" are proposed, it is noted that these concepts are not identical. Emphasis is placed on the nonreproducibility of land as a natural object.

It is noted that during the restoration of lands the state of lands is reduced from the existing negative to their inherent initial quality condition. The need to document changes in the state of the land is emphasized. The definition of the concept of "land restoration" is offered. Emphasis is placed on its various legal aspects.

The classification of land restoration measures is offered. Particular attention is paid to the main measures to restore the latter. It is proposed to distinguish the restoration of land in a broad sense from a narrow understanding of the term. Emphasis is placed on the peculiarities of the restoration of lands of different categories. It is emphasized that first of all the lands need to be restored due to illegal actions, at the same time in some cases the condition of the lands may be worsened due to legal actions.

The legal nature of the norms regulating public relations in the field of land restoration, their place in the system of land law is studied. Substantiated criteria for delimitation of protection and restoration of lands are offered, their interrelation is analyzed.

Features and place of restoration of a condition of the land plot in system of ways of protection of the broken rights to the lands are considered.

An analysis of the legal norms governing the rights and obligations in the relevant field. Gaps in the legal regulation in this area have been identified and appropriate proposals have been made. It is concluded that the economic mechanism is weak and the need to strengthen legal liability in the field of land reclamation. It is concluded that it is necessary to restore the systemic nature and develop and adopt the necessary regulations.

Key words: restoration, lands, soils, quality condition, fertility. 